| Pemberdayaan Anak Jalanan

\title{
UPAYA PEMBERDAYAAN ANAK JALANAN MELALUI RUMAH SINGGAH DIPONEGORO YOGYAKARTA
}

\author{
Ibnu Aribowo ${ }^{1}$
}

\begin{abstract}
Abstrak
Permasalahan anak jalanan sebagai permasalahan yang tak ada ujung pangkalnya, bagaikan lingkaran setan yang tak habis-habisnya. Dalam penangannya diperlukan adanya penelitian terhadap model pembinaan yang diterapkan, terutama pada model pembinaan melalui rumah singgah sebagai dasar penanganan pemecahan masalah. Tujuan penelitian ini adalah untuk mengetahui Program pemberdayaan anak jalanan yang ada di Rumah Singgah Diponegoro Yogyakarta. Penelitian ini diharapkan ditemukan pengembangan model pembinaan Rumah Singgah yang tepat sesuai kebutuhan dan tuntutan anak jalanan terutama di Rumah Singgah Diponegoro Yogyakarta.

Pendekatan penelitian yang digunakan adalah kualitatif deskriptif, yakni penelitian yang lebih ditekankan untuk memberikan gambaran secara obyektif tentang keadaan sebenarnya dari subyek yang diteliti. Subyek dalam penelitian ini adalah pengurus dan anak jalanan yang teridentifikasi di Rumah Singgah Diponegoro Yogyakarta Jl. Nogorojo No. 15 C, Gowok, Catur Tunggal, Sleman Yogyakarta yang diperoleh dengan teknik purposive sampling. Untuk memperoleh data yang diperlukan dan relevan dengan masalah maka teknik pengambilan data penelitian menggunakan observasi, wawancara dan dokumentasi. Teknik analisis data yang dilakukan meliputi reduksi data, deskripsi data dan penarikan kesimpulan atau verifikasi. Pemeriksaan keabsahan data mengunakan teknik triangulasi.

Hasil penelitian menunjukan bahwa: (1) anak jalanan yang ada di Kota Yogyakarta berasal dari berbagai daerah, diantaranya: Purworejo, Jakarta, Majenang, Jawa Timur dan daerah lain di sekitar Propinsi DI Yogyakarta, (2) untuk mengurangi jumlah anak jalanan Rumah Singgah Diponegoro berupaya memberdayakan anak jalanan dengan program-programnya seperti, identifikasi dan pendampingan, layanan kesehatan, bantuan makanan, pembinaan mental spiritual, beasiswa dan latihan keterampilan hidup, (3) anak jalanan yang dibina di Rumah Singgah Diponegoro memiliki bakat dan potensi, misalnya dalam hal musik telah membentuk grup band yang di beri nama Dip-@ Band dan menghasilkan album “Tuan-tuan Jalanan”. Kesulitan yang dihadapi Rumah Singgah Diponegoro dalam menjalankan program pemberdayaan adalah kurangnya bantuan dana dari Pemerintah dan masyarakat. Keberadaan Rumah Singgah Diponegoro sangat diperlukan oleh anak jalanan dan merupakan salah satu model alternatif pemberdayaan anak jalanan yang efektif dan efisien. Rumah Singgah Diponegoro telah berusaha
\end{abstract}

\footnotetext{
${ }^{1}$ Penulis adalah alumni Program Studi Pendidikan Sosiologi, FISE, Universitas Negeri Yogyakarta. Sekarang Guru di SMA N 3 Muko-Muko, Bengkulu
} 
merubah sikap dan pola hidup anak jalanan yang dibina untuk lebih hidup mandiri, kreatif dan normatif sehingga nantinya anak jalanan tidak turun ke jalanan lagi dan dapat hidup normal seperti anak-anak pada umumnya.

Kata Kunci: Anak Jalanan, Pemberdayaan, Rumah Singgah

\section{A. Pendahuluan}

Seiring dengan perkembangan zaman dewasa ini, semakin banyak fenomena sosial yang sering kita jumpai, terutama di kota - kota besar Indonesia yang sering muncul beberapa tahun ini, yaitu adanya anak jalanan. Mereka mengais rezeki di berbagai tempat keramaian kota. Kehadiran dan keberadaan anak jalanan tersebut mengundang perhatian dan sorotan masyarakat. Meskipun menjual jasa dan kegigihan dalam mencari penghasilan, namun banyak anggota masyarakat yang merasa prihatin dan juga merasa terganggu dengan keberadaan dan aktivitas mereka.

Kondisi semakin parah sejak krisis ekonomi yang terjadi pada tahun 1997. Permasalahan ini berdampak negatif bagi perekonomian masyarakat lapisan bawah. $^{2}$ Akibat lebih jauh, banyak anak yang mencari kegiatan agar dapat menghasilkan uang untuk membantu ekonomi orang tuanya dengan turun ke jalan dan banyak diantara mereka terpaksa meninggalkan sekolah guna mencari nafkah di jalan. Sehingga jumlah anak jalanan di kota-kota besar menunjukan peningkatan yang cukup tajam.

\footnotetext{
${ }^{2}$ Bagong Suyanto, Permasalahan-Permasalahan Strategis dalam Program Pemberdayaan Ekonomi Kerakyatan. Surabaya: Airlangga University Press, 2002, hlm. 1
}

Bagi bangsa indonesia, masyarakat, keluarga miskin dan terlebih lagi bagi anak-anak yang rawan mennjadi anak jalanan, situasi krisis ekonomi adalah awal mula dari timbulnya berbagai masalah yang sulit untuk dipecahkan dalam waktu singkat. Krisis ekonomi telah membuat kemiskinan menjadi semakin parah, sehingga menyebabkan situasi semakin sulit. Meskipun krisis ekonomi bukan satusatunya faktor pencipta anak jalanan, tetapi dampaknya sangat signifikan membuat daya tahan, perhatian dan kehidupan anak-anak menjadi makin marginal, terutama bagi anak-anak yang masuk dalam golongan rawan.

Berdasarkan data Badan

Kesejahteraan Nasional (BKSN), peningkatan anak jalanan sebelum krisis $15 \%$ dan angka itu meningkat hingga $100 \%$ dalam masa krisis, selain itu terungkap berbagai perlakuan eksploitasi dan perlakuan yang salah terhadap anak jalanan, misalnya penanganan yang cenderung represif dari Pemda demi kebersihan dan ketertiban kota ${ }^{3}$. Terlebih lagi adanya penolakan dari sebagian besar masyarakat terhadap kehadiran anak jalanan, dan bahkan hampir tak ada pelayanan yang dapat diakses oleh anak jalanan seperti: kesehatan, pendidikan,

\footnotetext{
BKSN. Anak Jalanan Di Indonesia: Permasalahan dan Penganannya . Jakarta : BKSN, 2000, hlm. 25
} 
perlindungan anak dan pelayanan lainnya.

Selain faktor ekonomi, banyak penyebab yang saling mempengaruhi turunnya anak ke jalan, seperti: kemiskinan, penganguran, perceraian dan kekerasan dalam rumah tangga. Jika tidak segera diatasi maka kondisi anak jalanan itu semakin gawat, dan masa depan mereka menjadi suram. Hal ini memungkinkan setelah dewasa mereka akan menjadi warga masyarakat yang menyusahkan orang lain. Padahal setiap masalah yang menyentuh kehidupan anak dalam jumlah yang besar akan berdampak tidak menguntungkan bagi kehidupan bangsa secara keseluruhan di masa mendatang.

Dalam buku yang bertajuk Daerah Istimewa Yogyakarta dalam angka menunjukan ada beberapa permasalahan dalam bidang pendudukan terutama besarnya penyandang masalah sosial. Pada tahun 2002 tercatat sebanyak 295.579 penduduk yang dikategorikan masalah sosial, sebagian besar yakni 82,6 \% merupakan fakir miskin, 6,49 $\%$ anak terlantar dan sisanya 10,91 \% adalah anak jalanan, anak nakal, gelandangan, Wanita tuna susila, korban narkotika, eks Napi, wanita rentan masalah sosial dan keluarga yang rumahnya tak layak huni ${ }^{4}$. Menurut data Kanwil Depsos Daerah Istimewa Yogyakarta tahun 19992000 jumlah anak jalanan di kota Yogyakarta tercatat 1378 anak yang terbagi dalam daerah Dati II yaitu : Kota Madya Yogyakarta ada 582

\footnotetext{
${ }^{4}$ BPS 1403.34 , Yogyakarta Dalam Angka. BPS Propinsi Daerah Istimewa Yogyakarta, Yogyayakarta:, 2002,hlm. 63
}

anak, Bantul 28 anak, Kulon Progo 100 anak, Gunung Kidul 82 anak dan sleman 825 anak 5 .

Untuk mengatasi masalah mendapatkan dukungan dari berbagai sektor baik aparat pemerintah terkait, LSM, Pers dan Masyarakat. Komitmen yang dibangun bersama lintas sektor ini akan sangat membantu mempercepat proses keberhasilan penanganan masalah anak jalanan. Permasalahan anak jalanan ini tidak henti-hentinya disoroti sebagai permasalahan yang tak ada ujung pangkalnya bagaikan lingkaran setan yang tak habis-habis. Hal inilah yang menjadi faktor peneliti tertarik dan ingin turut memberikan sumbangan pemikiran dalam upaya pengentasan anak jalanan melalui pembuatan skripsi yang terfokus pada Upaya Pemberdayaan Anak Jalanan Melalui Rumah Singgah Diponegoro Yogyakarta.

Titik persoalan ini diperlukan adanya penelitian terhadap model pembinaan yang diterapkan, terutama pada model pembinaan melalui rumah singgah sebagai dasar penanganan pemecahan masalah yang terjadi. Selanjutnya diharapkan model pembinaan Rumah Singgah sesuai kebutuhan dan tuntutan anak jalanan terutama di Rumah Singgah Diponegoro Yogyakarta. Dalam pembinaan anak jalanan yang tepat sesuai kebutuhan dan harapan ada hal-hal tertentu yang menjadi faktor utama yang patut diperhatikan yakni faktor dari dalam dan faktor dari

\footnotetext{
${ }^{5}$ Surat Kabar Minguan Pagi. 1 Desember 2001. hlm. 5 .
} 
luar. Faktor dari dalam adalah potensi dan kelemahan yang ada, sedangkan faktor dari luar adalah peluang dan hambatan. Pada kedua faktor tersebut terdapat hal-hal tertentu yang patut diperhatikan yang menjadi kunci dalam mencari format pembinaan yang tepat bagi anak jalanan. Contoh orang-orang yang menjadi sosok terkenal yang dulunya anak jalanan adalah : Mc. Tyson (petinju kelas dunia), Mickel Jakson (artis penyanyi internasional), Didi Kempot (penyanyi campur sari), Iwan Fals (penyanyi terkenal) dan Taufik Safalas (pelawak dan presenter). ${ }^{6}$ Demikian juga dengan Rumah Singgah Diponegoro telah mencetak grup band yang di berinama Dip-@ Band.

Dari beberapa tokoh atau artis yang berhasil tersebut dapat ditarik kesimpulan bahwa dalam diri setiap manusia pasti terdapat potensi dasar yang dapat ditumbuhkembangkan. Upaya mencari format pengembangan model pada pembinaan anak jalanan melalui rumah singgah ini akan dilakukan dengan mengali potensi, kelemahan, peluang dan hambatan dari permasalahan anak jalanan yang akan dipadukan dengan pola pendekatan yang ada sesuai dengan kebutuhan dan tuntutan dari anak jalanan itu sendiri.

Tujuan penelitian ini adalah:

1) untuk mengetahui programprogram apa saja yang diberikan Rumah Singgah dalam upaya

6 Astutik, D. (2005). Pengembangan Model Pembinaan Anak Jalanan Melalui Rumah Singgah di Jawa Timur. Tersedia pada http://www.damandiri.or.id/detail.php?id=325 Diakses pada tanggal 3 Januari 2008. pemberdayaan dan yang diharapkan anak jalanan agar dapat bermanfaat dan berguna dalam hidupnya setelah keluar dari Rumah Singgah Diponegoro Yogyakarta, 2) untuk mengetahui apakah ada kesulitankesulitan dalam pemberdayaan anak jalanan melalalui Rumah Singgah Diponegoro Yogyakarta, 3) melihat ketercapaian dan keberhasilan pelaksanaan program pemberdayaan anak jalanan melalalui Rumah Singgah Diponegoro Yogyakarta.

\section{A. Kajian Teori}

\section{Anak Jalanan}

Istilah anak jalanan pertama kali diperkenalkan di Amerika selatan, tepatnya di Brazilia, dengan nama Meninos de Ruas untuk menyebut kelompok anak-anak yang hidup di jalanan dan tidak memiliki tali ikatan dengan keluarga. Di beberapa negara lain istilah anak jalanan berbeda-beda. Di Colombia anak jalanan disebut "gamin" (urchin atau melarat) dan "chinches" (kutu kasur), "marginais" (kriminal atau marginal) di Zaire dan Konggo disebut "balados" (pengembara) ${ }^{7}$. Istilah ini mengambarkan bagaimana rendahnya posisi anak-anak jalanan dalam masyarakat, mengangap anak jalanan adalah anak yang sudah tidak memiliki masa depan, liar, kumuh dan pelabelan buruk lainya.

Pengertian anak jalanan yang dikeluarkan oleh Dinas Sosial Propinsi Daerah Istimewa Yogyakarta adalah anak yang melewatkan atau memanfaatkan sebagian besar waktunya untuk melakukan kegiatan sehari-hari di

\footnotetext{
${ }^{7}$ Ibid.
} 
jalanan. Sementara itu di dalam buku "Intervensi Psikososial", anak jalanan adalah anak yang sebagian besar menghabiskan waktunya untuk mencari nafkah atau berkeliaran di jalan atau tempat umum lainnya ${ }^{8}$.

Secara garis besar anak jalanan dibedakan dalam tiga kelompok ${ }^{9}$ : Pertama, children on the street, yakni anak-anak yang mempunyai kegiatan ekonomi sebagai pekerja di jalan, tetapi masih mempunyai hubungan yang kuat dengan orang tua mereka. Sebagian penghasilan mereka di jalanan pada kategori ini adalah untuk membantu memperkuat penyangga ekonomi keluarganya karena beban atau tekanan kemiskinan yang mesti ditanggung tidak dapat diselesaikan sendiri oleh kedua orang tuannya.

Kedua, children of the street, yakni anak-anak yang berpartisisipasi penuh di jalanan, baik secara sosial maupun ekonomi. Beberapa diantara mereka masih mempunyai hubungan dengan orang tuanya, tetapi frekwensi pertemun mereka tidak menentu. Banyak diantara mereka adalah anak-anak yang karena sebab, biasanya kekerasan, lari atau pergi dari rumah. Berbagai penelitian menunjukan bahwa anak-anak pada kategori ini sangat rawan terhadap perlakuan salah, baik secara sosial, emosional, fisik maupun seksual.

Ketiga, children from families of the street, yakni anak-anak yang berasal dari keluarga jalanan.

\footnotetext{
${ }^{8}$ Depsos. Intervensi Psikososial. Jakarta : Direktorat kesejahteraan Anak Keluarga dan Lanjut Usia, 2001. hlm.20.

${ }^{9}$ Ibid
}

Meskipun anak-anak ini mempunyai hubungan kekeluargaan yang cukup kuat, tetapi hidup mereka terombang-ambing dari satu tempat ke tempat lain dengan segala resikonya.

Dalam buku "Intervensi Psikososial" karakteristik anak jalanan dapat dilihat dalam tabel berikut ${ }^{10}$ :

Tabel 1.

Ciri-ciri Fisik dan Psikis Anak Jalanan

\begin{tabular}{|c|c|}
\hline Ciri Fisik & Ciri Psikis \\
\hline $\begin{array}{l}\text { - Warna kulit } \\
\text { kusam } \\
\text { - Rambut } \\
\text { kemerah- } \\
\text { merahan } \\
\text { - Kebanyakan } \\
\text { berbadan } \\
\text { kurus } \\
\text { - Pakaian tidak } \\
\text { terurus }\end{array}$ & $\begin{array}{l}\text { - Mobilitas } \\
\text { tinggi } \\
\text { - Penuh curiga } \\
\text { - Sangat sensitif } \\
\text { - Kreatif } \\
\text { - Semangat } \\
\text { hidup tinggi } \\
\text { - Berani } \\
\text { menangung } \\
\text { resiko } \\
\text { - Mandiri }\end{array}$ \\
\hline
\end{tabular}

Kebanyakan

orang beranggapan bahwa faktor utama yang menyebabkan anak turun ke jalan untuk bekerja dan hidup di jalan adalah karena faktor kemiskinan. Namun dari data literatur yang ada menunjukan bahwa kemiskinan bukanlah satusatunya faktor penyebab anak turun ke jalan. Tiga tingkatan penyebab anak turun ke jalanan ${ }^{11}$ :

\footnotetext{
${ }^{10}$ Depsos. Intervensi Psikososial. Jakarta : Direktorat kesejahteraan Anak Keluarga dan Lanjut Usia. 2001, hlm. 23-24.

${ }^{11}$ Depsos , Pelayanan Sosial Anak, Jakarata: Direktorat Jendral Pelayanan dan Rehabilitasi Sosial, 2002, hlm. 25-26.
} 
1) Tingkat mikro (immediate causes), yaitu faktor yang berhubungan dengan anak dan keluarganya, Tingkat mikro anak jalanan disebabkan oleh beberapa faktor yaitu: a) Lari dari keluarga, b) Terlantar

2) Tingkat messo (underlying causes), yaitu faktor yang ada di masyarakat, pada tingkat messo (masyarakat) sebab yang dapat diidentifikasi yaitu: Pada masyarakat miskin anak-anak adalah aset untuk membantu pemenuhan kebutuhan keluarga, anakanak diajarkan bekerja yang berakibat drop out dari sekolah.

3) Tingkat makro (basic causes), yaitu faktor yang berhubungan dengan struktur makro. Pada tingkat makro (struktur masyarakat) ini faktor penyebabnya yang dapat diidentifikasi yaitu :

a) Ekonomi adalah adanya peluang pekerjaan sektor informal yang tidak terlalu mebutuhkan modal keahlian

b)Pendidikan adalah biaya sekolah yang tinggi dan birokratis yang mengalahkan kesempatan belajar

\section{Rumah Singgah}

Secara harfiah Rumah Singgah berarti suatu tempat berhenti sebentar ketika di perjalanan untuk mampir atau istirahat, tetapi mencakup berbagai tempat kegiatan dan dimanfaatkan sebagai model sarana pembinaan anak jalanan. Tujuan umum Rumah Singgah adalah membantu anak jalanan menagatasi masalah-masalahnya dan menemukan alternatif untuk pemenuhan kebutuhan hidupnya. Sedangkan tujuan khususnya adalah $^{12}$ :

a. Membentuk kembali sikap dan perilaku anak yang sesaui dengan nilai dan norma yang berlaku di masyarakat

b. Mengupayakan anak-anak kembali ke rumah jika memungkinkan atau ke panti dan lembaga pengati lainnya jika diperlukan

c. Memberikan berbagai alternatif pelayanan untuk pemenuhan kebutuhan anak dan menyiapkan masa depanya sehingga menjadi warga masyarakat yang produktif.

Sedangkan fungsi dari rumah singgah adalah sebagai berikut ${ }^{13}$ :

a. Tempat pertemuan pekerja sosial dengan anak jalanan

b. Perantara antara anak jalanan dengan orang tua

c. Perlindungan anak dari kekerasan dan penyalahgunaan

d. Pusat informasi tentang anak jalanan

e. Jalur masuk pelayanan sosial

f. Tempat pengenalan nilai dan norma sosial pada anak jalanan.

Jadi rumah singgah adalah suatu tempat perantara anak jalanan dengan pihak-pihak yang ingin membantu mereka, selain itu juga di rumah singgah ini anak jalanan mendapatkan pelayanan, pembinaan dan pendampingan.

\footnotetext{
${ }^{12}$ Astutik, op.cit, hlm. 32-33.

${ }^{13}$ Ibid.
} 


\section{Pemberdayaan Anak Jalanan}

Pemberdayaan anak jalanan bisa dilakukan apabila telah melalui tahap pengkajian secara mendalam terhadap kebutuhan dan potensi anak jalanan serta faktor-faktor yang melatar belakangi anak turun ke jalan. Tahap awal dalam pemberdayaan anak jalanan yang dilakukan Rumah Singgah Diponegoro adalah melakukan identifikasi agar dapat diklasifikasi dalam kelompok-kelompok tertentu. Selanjutnya dapat diketahui adanya potensi tertentu yang melekat pada diri anak jalanan. Potensi ini menurut Badan Kesejahteraan Sosial Nasional (BKSN) dapat dilihat dari dua sisi, yaitu potensi yang melekat pada diri anak jalanan sebagai individu dan sebagai suatu kelompok dari warga masyarakat dan potensi yang terdapat di lingkungan sosialnya baik keluarga ataupun masyarakat sekitarnya.

Potensi pada diri anak jalanan, misalnya kecerdasan intelektual atau intelectual quetion (IQ) yang tinggi bisa diberdayakan melalui pendidikan, diberi beasiswa dan sarana pendukung lainnya dengan harapan anak jalanan bisa kembali ke sekolah lagi bagi anak yang putus sekolah . Pemberdayaan tersebut tidak hanya berhenti pada pemberian bantuan awal saja, namun semua bentuk bantuan baik berupa pendidikan atau wirausaha harus dilanjutkan pada tahap pengembangan dan pemberdayaan lanjutan hingga anak jalanan menjadi mandiri

\section{Pemberdayaan Rumah Singgah}

Rumah Singgah atau Lembaga sosial penampung anak jalanan setidaknya harus memiliki lima bagian atau staf untuk menjalankan aktivitas dan pekerjaan sosialnya. Bagian-bagian tersebut adalah: supervisor, pemimpin rumah singgah atau lembaga, pekerja sosial, ketua kelompok anak jalanan, dan tenaga administratif ${ }^{14}$.

Lembaga penampung atau Rumah Singgah anak jalanan harus memiliki jaringan kerja, baik dengan instansi pemerintah ataupun dengan lembaga-lembaga atau rumah singgah lainnya. Berikut ini beberapa alternatif tempat rujukan atau sarana pendukung:

${ }^{14}$ BKSN, loc.cit, hlm.100-103. 
Gambar 1.

Beberapa alternatif tempat rujukan

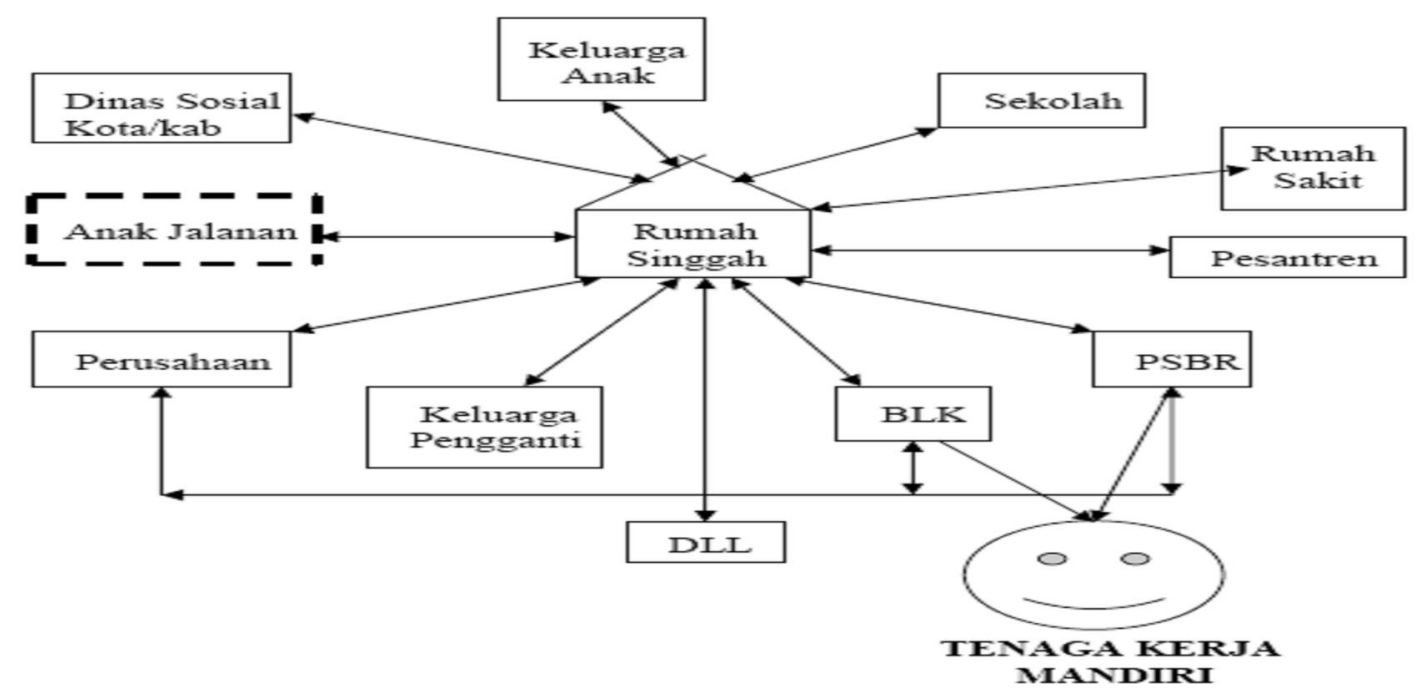

Dengan jaringan atau alternatif rujukan di atas, diharapkan Rumah Singgah atau lembaga penampung anak jalanan dapat memberikan pelayanan yang maksimal bagi anak jalanan.

\section{B. Pembahasan}

\section{Deskripsi Karakter Subyek} Penelitian Anak jalanan Rumah Singgah Diponegoro Yogyakarta Rentang usia anak jalanan di sini adalah usia sekolah (6-18 tahun) dan ada yang lebih dari itu. Anak jalanan tersebut ada yang tidak sekolah dan ada yang masih sekolah baik tingkat SD, SMP dan SMA. Bagi mereka yang masih sekolah, biasanya setelah pulang dan sore sampai malam hari. Berdasarkan informasi dari penelitian yang di dapat di lapangan bahwa pada umumunya Anak jalanan yang ada di Yogyakarta dan dibina oleh Rumah Singgah Diponegoro adalah pada usia produktif. anak jalanan adalah anak usia sekolah, maka pendidikan harus diutamakan bagi mereka. Meskipun ada beberapa anak yang berpendapat bahwa pendidikan tidaklah penting jika tidak mempunyai keterampilan dan keahlian. Bagi anak jalanan yang masih sekolah tingkat SD dan SMP mereka tidak malu untuk memintaminta dan mengamen di jalanan, sedangkan anak yang sudah masuk SMA mereka cenderung malu untuk mengamen dan lebih memilih menjual koran. Anak jalanan yang teridentifikasi oleh Rumah Singgah yang masih sekolah diupayakan mendapatkan bantuan beasiswa.

Dari hasil wawancara selama penelitian sebagian anak jalanan bukan berasal dari Kota Yogyakarta saja, melainkan dari luar Yogyakarta. Anak jalanan yang dibina di Rumah Singgah Diponegoro ada yang berasal dari Semarang, Jakarta, Kutoarjo, Surabaya dan Manjenang. Mereka sampai ke Yogyakarta 
dengan cara ikut Kereta Api dan Busbus yang menuju ke Yogyakarta. setelah sampai anak jalanan biasanya menjual jasa seperti : mengamen, menyemir sepatu dan menjual jasa lainnya.

Jarak tempuh tempat tinggal dengan lokasi tempat mangkal mereka rata-rata tidak jauh dengan tempat tinggal mereka, sehingga memudahkan mereka untuk kembali ke rumah dan ke sekolah. Lokasi mangkal mereka biasanya di pertigaan dan perempatan jalan, misalnya di pertigaan UIN Sunan Kali Jaga, pertigaan Janti, Perempatan Demangan, Pertigaan Colombo dan pertigaan Maguwoharjo.

Jenis pekerjaan yang digeluti oleh Anak jalanan di Rumah singgah Diponegoro, yaitu: ngamen, menjual koran, dan menyemir sepatu. Dari data lapangan yang peneliti peroleh menunjukkan bahwa sebagian besar anak jalanan tersebut berprofesi sebagai penjual koran. Koran diperoleh dari agen koran pengecer tertentu dengan sistem komisi (hanya menjualkan saja tanpa menggunakan modal). Pengurus Rumah Singgah Diponegoro sangat senang dengan berpindahnya profesi anak jalanan dari mengamen menjadi penjual koran, karena dengan menjual koran secara tidak langsung telah melatih anak jalanan untuk berusaha dan menjadi lebih mandiri dengan tidak terlalu ketergantungan dengan orang lain.

2. Program Rumah Singgah Diponegoro dalam Upaya Pemberdayaan Anak Jalanan

a. Penjangkauan dan Identifikasi Program penjangkauan dan identifikasi anak jalanan dilakukan para relawan dengan cara turun langsung ke lokasi yang menjadi tempat anak jalanan mengais rezeki, seperti di perempatan Universitas Islam Negeri Sunan Kalijaga Yogyakarta, Demangan, Pertigaan Colombo, Santikara, Perempatan Condong Catur, Perempatan Cemara Tujuh/ Kentungan, Perempatan Novotel dan Lempuyangan.

Pada tempat tersebut para relawan melakukan pendampingan pada anak jalanan. Pendampingan tersebut bersifat personal dan komunal. Selain itu, para relawan juga memperkenalkan Rumah Singgah Diponegoro Yogyakarta dengan menginformasikan segala manfaat dan fasilitas yang diperoleh dari program kegiatan yang ada. Identifikasi anak jalanan Rumah Singgah Diponegoro Yogyakarta tahun pada tahun 2008 dapat mengidentifikasi anak jalanan sebagai berikut: 
Tabel 2.

Daftar Identifikasi Anak Jalanan

Rumah Singgah Diponegoro Yogyakarta Tahun 2008

\begin{tabular}{|c|c|c|c|c|}
\hline No. & Nama & Usia & Alamat & Keterangan \\
\hline 1 & $\begin{array}{l}\text { Uswatu } \\
\text { Khasanah }\end{array}$ & $\begin{array}{c}16 \\
\text { tahun }\end{array}$ & Nologaten Sleman & Anjal \\
\hline 2 & $\begin{array}{l}\text { Herman } \\
\text { Supriyadi }\end{array}$ & $\begin{array}{c}17 \\
\text { tahun }\end{array}$ & RSG Diponegoro & Anjal \\
\hline 3 & M. Arifin & $\begin{array}{c}14 \\
\text { tahun }\end{array}$ & RSG Diponegoro & Anjal \\
\hline 4 & Partini & $\begin{array}{c}17 \\
\text { tahun }\end{array}$ & Papringan Sleman & Anjal \\
\hline 5 & $\begin{array}{l}\text { Taufiq } \\
\text { Prihantono }\end{array}$ & $\begin{array}{c}17 \\
\text { tahun }\end{array}$ & RSG Diponegoro & Anjal \\
\hline 6 & Rino Aji Prasetyo & $\begin{array}{l}16 \\
\text { tahun }\end{array}$ & RSG Diponegoro & Anjal \\
\hline 7 & Retno Dwi Astuti & $\begin{array}{c}14 \\
\text { tahun }\end{array}$ & $\begin{array}{l}\text { Maguwo } \\
\text { Yogyakarta }\end{array}$ & Rentan \\
\hline 8 & Tri Purwaningsih & $\begin{array}{c}17 \\
\text { tahun }\end{array}$ & Papringan Sleman & Rentan \\
\hline 9 & Supardiyanto & $\begin{array}{c}16 \\
\text { tahun }\end{array}$ & Gowok Sleman & Rentan \\
\hline 10 & Solin Betani & $\begin{array}{c}18 \\
\text { tahun }\end{array}$ & $\begin{array}{l}\text { Nogomodo } \\
\text { Sleman }\end{array}$ & Rentan \\
\hline 11 & Sigit Prasetyo & - & $\begin{array}{l}\text { Muntilan } \\
\text { Magelang }\end{array}$ & Rentan \\
\hline 12 & M. Refi Jaelani & $\begin{array}{c}17 \\
\text { tahun }\end{array}$ & Papringan Sleman & Anjal \\
\hline 13 & Edi Kurniawan & $\begin{array}{c}17 \\
\text { tahun }\end{array}$ & RSB Diponegoro & Anjal \\
\hline 14 & Okta Trinugroho & $\begin{array}{c}18 \\
\text { tahun }\end{array}$ & Papringan Sleman & Anjal \\
\hline 15 & Arif Budiyono & $\begin{array}{c}18 \\
\text { tahun }\end{array}$ & RSB Diponegoro & Anjal \\
\hline 16 & Kasno Wibowo & $\begin{array}{c}16 \\
\text { tahun }\end{array}$ & $\begin{array}{l}\text { Ambarukmo } \\
\text { Sleman }\end{array}$ & Anjal \\
\hline 17 & Sawaludin & - & RSB Diponegoro & Anjal \\
\hline 18 & Girianto & $\begin{array}{c}18 \\
\text { tahun }\end{array}$ & $\begin{array}{l}\text { Ambarukmo } \\
\text { Sleman }\end{array}$ & Anjal \\
\hline 19 & Budi Sahawatik & - & Papringan Sleman & Anjal \\
\hline 20 & Lilik Setiawan & $\begin{array}{c}14 \\
\text { tahun }\end{array}$ & Dlingo Bantul & Anjal \\
\hline 21 & Imron & - & Nologaten Sleman & Anjal \\
\hline
\end{tabular}




\begin{tabular}{|c|c|c|c|c|}
\hline 22 & Ria Defka & $\begin{array}{c}17 \\
\text { tahun }\end{array}$ & $\begin{array}{l}\text { Banguntapan } \\
\text { Bantul }\end{array}$ & Anjal \\
\hline 23 & Nuryanti & $\begin{array}{c}18 \\
\text { tahun }\end{array}$ & $\begin{array}{l}\text { Banguntapan } \\
\text { Bantul }\end{array}$ & Rentan \\
\hline 24 & Tri Nurul Utami & $\begin{array}{c}16 \\
\text { tahun }\end{array}$ & $\begin{array}{l}\text { Ncari Gunung } \\
\text { Kidul }\end{array}$ & Rentan \\
\hline 25 & $\begin{array}{l}\text { Singgih } \\
\text { Pamungkas }\end{array}$ & $\begin{array}{c}18 \\
\text { tahun }\end{array}$ & Sorowajan Bantul & Rentan \\
\hline 26 & $\begin{array}{l}\text { Nency Karlinda } \\
\text { Sari }\end{array}$ & $\begin{array}{c}16 \\
\text { tahun }\end{array}$ & $\begin{array}{l}\text { Banguntapan } \\
\text { Bantul }\end{array}$ & Rentan \\
\hline 27 & Angga & $\begin{array}{c}17 \\
\text { tahun }\end{array}$ & $\begin{array}{l}\text { Ambarukmo } \\
\text { Sleman }\end{array}$ & Anjal \\
\hline 28 & Evi Rean Segan & $\begin{array}{c}18 \\
\text { tahun }\end{array}$ & $\begin{array}{l}\text { Ambarukmo } \\
\text { Sleman }\end{array}$ & Rentan \\
\hline 29 & Siti Artinah & $\begin{array}{c}11 \\
\text { tahun }\end{array}$ & $\begin{array}{l}\text { Ambarukmo } \\
\text { Sleman }\end{array}$ & Anjal \\
\hline 30 & Aldes Herawati & $\begin{array}{c}16 \\
\text { tahun }\end{array}$ & Baciro Yogyakarta & Anjal \\
\hline 31 & Yasin & - & RSB Diponegoro & Anjal \\
\hline 32 & M. Arifin & $\begin{array}{l}16 \\
\text { tahun }\end{array}$ & RSB Diponegoro & Anjal \\
\hline 33 & M. Jarianto & $\begin{array}{c}17 \\
\text { tahun }\end{array}$ & RSB Diponegoro & Anjal \\
\hline 34 & $\begin{array}{l}\text { Gelar Deki } \\
\text { Saputro }\end{array}$ & $\begin{array}{c}15 \\
\text { tahun }\end{array}$ & $\begin{array}{l}\text { Umbulharjo } \\
\text { Yogyakarta }\end{array}$ & Anjal \\
\hline 35 & Tri Wibowo & $\begin{array}{c}17 \\
\text { tahun }\end{array}$ & Papringan Sleman & Anjal \\
\hline 36 & Triyono & $\begin{array}{c}18 \\
\text { tahun }\end{array}$ & $\begin{array}{l}\text { Ambarukmo } \\
\text { Sleman }\end{array}$ & Anjal \\
\hline 37 & Fitri Alfiah & - & Gowok Sleman & Rentan \\
\hline 38 & $\begin{array}{l}\text { Ayu } \\
\text { Ihtiarningsih }\end{array}$ & $\begin{array}{c}10 \\
\text { tahun }\end{array}$ & $\begin{array}{l}\text { Banguntapan } \\
\text { Bantul }\end{array}$ & Rentan \\
\hline 39 & Rizki Darmawan & 17tahun & RSB Diponegoro & Anjal \\
\hline 40 & Barokah & - & Nologaten Sleman & Anjal \\
\hline 41 & Agus Setiyawan & - & $\begin{array}{l}\text { Sanggar } \\
\text { Yogyakarta }\end{array}$ & Anjal \\
\hline 42 & Lestiyono & - & RSB Diponegoro & Anjal \\
\hline 43 & Budiyono & $\begin{array}{c}16 \\
\text { tahun }\end{array}$ & RSB Diponegoro & Anjal \\
\hline 44 & Bambang Irawan & $\begin{array}{c}16 \\
\text { tahun }\end{array}$ & RSB Diponegoro & Anjal \\
\hline 45 & $\begin{array}{l}\text { Andik } \\
\text { Nurdiyansyah }\end{array}$ & $\begin{array}{c}15 \\
\text { tahun }\end{array}$ & RSB Diponegoro & Anjal \\
\hline 46 & Aga Santoso & 15 & Bandung & Anjal \\
\hline
\end{tabular}




\begin{tabular}{|c|l|c|l|c|}
\hline 47 & $\begin{array}{l}\text { tahun } \\
\text { Kurniyawan }\end{array}$ & - & $\begin{array}{l}\text { RM Sangar } \\
\text { Monjali }\end{array}$ & Anjal \\
\hline 48 & $\begin{array}{l}\text { Dimas } \\
\text { Adesetiawan }\end{array}$ & $\begin{array}{c}13 \\
\text { tahun }\end{array}$ & Ngentak Sapen & Anjal \\
\hline 49 & Satini & $\begin{array}{c}13 \\
\text { tahun }\end{array}$ & Papringan Sleman & Anjal \\
\hline 50 & Edi Priyanto & $\begin{array}{c}17 \\
\text { tahun }\end{array}$ & Semarang & Anjal \\
\hline 51 & Inul & $\begin{array}{c}11 \\
\operatorname{tahun}\end{array}$ & Ponorogo & Anjal \\
\hline
\end{tabular}

Sumber : Dokumen Rumah Singgah Diponegoro Yogyakarta

Hasil

identifikasi

menunjukkan bahwa tidak semua permasalahan ditemukan. Hal ini disebabkan beberapa dari mereka bersikap, sehingga tidak semuanya bisa diarahkan untuk mengikuti program kegiatan pemberdayaan yang ada di Rumah Singgah Diponegoro Yogyakarta.

b. Layanan Kesehatan

Masalah kesehatan bagi anak jalanan perlu mendapat perhatian yang serius, karena lingkungan dan cara hidup anak jalanan yang bebas yang sangat memungkinkan menularnya bebagai penyakit berbahaya yang dapat mengancam keselamatan jiwa mereka. Untuk itu Rumah Singgah Diponegoro Yogyakarta telah berkerja sama dengan Dinas Kesehatan dan Perlindungan Anak Propinsi Daerah Istimewa Yogyakarta. Dengan cara pemberian kartu sehat dan pengobatan gratis bagi anak jalanan, dan cek kesehatan dilakukan secara masal dilakukan dua kali dalam setahunnya di Rumah Singgah Diponegoro Yogyakarta. Rumah sakit yang menjadi mitra kerjasama Rumah Singgah Diponegoro selama ini adalah Rumah Sakit Sarjito dan Rumah Sakit Kasih Ibu.

c. Beasiswa Sekolah

Rumah Singgah Diponegoro Yogyakarta mengupayakan anak jalanan yang dapat dibina dan mempunyai kemauan untuk bersekolah memberikan bantuan beasiswa tahunan, dengan maksud agar anak jalanan bersemangat untuk sekolah dan meningalkan jalanan. Karena mereka sudah mendapatkan bantuan untuk bersekolah dan tidak perlu lagi mencari uang di jalanan.

Berdasarkan informasi yang diperoleh, bantuan beasiswa kepada anak-anak jalanan hanya bersifat membantu tergantung dengan kondisi keuangan Rumah Singgah Diponegoro. Tidak ada jumlah nominal tetap untuk tiap bulannya baik untuk SD, SMP dan SMA. Hal ini dilakukan agar orang tua anak jalanan ikut bertangung jawab membiayai biaya sekolah anakanaknya dan tidak terlepas sepenuhnya biaya ditangung oleh Rumah Singgah Diponegoro. 
d. Pembinaan Seni

Untuk menyalurkan minat dan bakat anak jalanan maka Rumah Singgah Diponegoro Yogyakarta membentuk grup band yang diberi nama Dip-@ Band. Kegiatan ini mendapat dukungan dan bantuan dari Grup Band papan atas di negeri ini yaitu Sheila On 7, dan semenjak mendapat bantuan dari Sheila On - 7 keberadaan Dip-@ Band semakin diminati dan mendapatkan banyak pengemar. Hingga saat ini Dip-@ Band telah menyelesaikan album perdananya yaitu "Tuan-tuan Jalanan" dengan berkolaborasi dengan bandband Rumah Singgah yang ada di Yogyakarta.

e. Tambahan Makanan

Rumah Singgah Diponegoro selain memberikan fasilitas asrama juga diberikan biaya makan secara gratis bagi anak jalanan. Karena bagi anak jalanan kebutuhan makanan sangat perlu diperhatikan terutama bagi mereka yang tidak tingal bersama dengan orang tuanya. Tambahan pemberian makanan ini sangat membantu sekali bagi anak jalanan, karena kualitas makanan dan gizi yang terkandung dalam makanan dapat terjamin, sehingga anak jalanan tidak mengalami ganguan kesehatan dan kekurangan gizi akibat pola makan yang tidak sehat. Pemberian makan yang ada di Rumah Singgah Diponegoro yaitu dengan cara penyediaan peralatan masak dan bahan makanan untuk dikelola, sehingga secara tidak langsung telah melatih anak jalanan untuk lebih terbiasa hidup mandiri dan agar tidak selalu tergantung dengan orang lain. Menurut anak jalanan pemberian makan sangat membantu sekali, karena bagi mereka kebutuhan makanan merupakan hal yang sangat diperlukan untuk memenuhi kebutuhan kesehatan dan menghindari kekurangan gizi.

Dengan program ini pengurus Rumah Singgah Diponegoro berharap agar kebutuhan gizi anak jalanan tetap terpenuhi dan selain itu juga pola makan anak jalanan lebih teratur dan terjaga kebersihannya. Pemberian makanan ini diberikan kepada anak jalanan yang tinggal di Rumah Singgah Diponegoro antara 9-13 anak jalanan, dan jumlah tersebut selalu berubah-ubah karena anak jalanan selalu tidak berada di Rumah Singgah Diponegoro.

Untuk menambah rasa kebersamaan antara penghuni Rumah Singgah dengan Pengurus maka setiap hari sabtu sore Rumah Singah Diponegoro mengadakan masak-masak dan makan bersama. Hal ini selain sebagai penambah gizi anak-anak jalanan juga dimaksudkan agar ada rasa kasih sayang dan kedekatan antar anak jalanan yang menghuni di Rumah Singgah Diponegoro dengan pengurus.

Dengan demikian pemberian makan kepada anak jalanan merupakan program pemberdayaan anak jalanan yang sangat penting dan diharapkan agar tetap ada di Rumah singgah karena sangat dibutuhkan untuk perkembangan dan pertumbuhan anak jalanan. Berikut adalah daftar penerima bantuan permakanan anak binaan Rumah Singgah Diponegoro tahun 2008 : 
Tabel 3.

Daftar Penerima Bantuan Permakanan Anak Rumah Singgah Diponegoro Yogyakarta Tahun 2008

\begin{tabular}{|c|l|c|c|c|}
\hline No. & \multicolumn{1}{|c|}{ Nama } & Usia & Alamat & Keterangan \\
\hline 1 & Edi Prayetno & 17 & Semarang & Anjal \\
\hline 2 & Rizki Darmawan & 18 & - & Anjal \\
\hline 3 & Lestiyono & 14 & Kutoarjo & Anjal \\
\hline 4 & Budiyono & 16 & Kutoarjo & Anjal \\
\hline 5 & $\begin{array}{l}\text { Andik } \\
\text { Nurdiansyah }\end{array}$ & 17 & Surabaya & Anjal \\
\hline 6 & $\begin{array}{l}\text { Gusti Palela } \\
\text { Ridlo }\end{array}$ & 14 & Majenang & Anjal \\
\hline 7 & M Jariyanto & 17 & Purbalingga & Anjal \\
\hline 8 & Imron & 8 & Nologaten & Rentan \\
\hline 9 & Triyono & 17 & Ambarukmo & Rentan \\
\hline
\end{tabular}

Sumber : Dokumen Rumah Singgah Yogyakarta Tahun 2008

f. Pendidikan Keterampilan Hidup

Keterampilan atau kecakapan hidup bagi anak jalanan sangat penting karena dengan cepatnya perubahan sosial dewasa ini menuntuk kita semua untuk mampu bersaing dalam merebut pekerjaan bagi mereka yang mencari pekerjaan dan mempertahankan usaha agar tetap berdiri dan mampu bersaing dengan pemodal asing bagi mereka yang mendirikan usaha sendiri. Rumah Singgah Diponegoro sejak mulai didirikan telah menyelengaran program ini. Kursus keterampilan yang diselenggarakan di Rumah Singgah Diponegoro Yogyakarta meliputi: pembuatan pigura, kursus jahit, perikanan dan mengadakan pelatihan perakitan komputer.
Program

Pelatihan keterampilan sangat diperlukan oleh anak jalanan binaan Rumah Singgah Diponegoro, karena diharapkan mampu membekali anak jalanan untuk membuka usaha sendiri dan tidak turun ke jalanan atau ketergantungan dengan orang lain.

g. Permodalan Usaha Kerja

Rumah Singgah Diponegoro Yogyakarta mengupayakan bagi anak jalanan yang sudah selesai mengikuti kursus keterampilan difasilitasi permodalan yang diharapkan nantinya mampu berlatih dan bekerja mandiri dengan bekal keterampilan dan modal usaha agar tidak tergantung dengan orang lain. Berikut adalah daftar penerima permodalan usaha dari Rumah Singgah Diponegoro Yogyakarta : 
Tabel 4.

Daftar Penerima Permodalan Usaha

\begin{tabular}{|l|l|l|}
\hline No & \multicolumn{1}{|c|}{ Nama } & \multicolumn{1}{c|}{ Bantuan / Usaha } \\
\hline 1 & Wahidi & Peralatan Batik \\
\hline 2 & Budi Handoko & Alat Buat Tempe \\
\hline 3 & Reni Sarjono & Alat Buat Tempe \\
\hline 4 & M. Syaifudin & Ternak Ayam \\
\hline 5 & Dedet & Alat Bengkel \\
\hline 6 & Faisal Hasni & Kelontong \\
\hline 7 & Nanang Susilo & Satu Set Mesin Jahit \\
\hline 8 & Mahmudah & Satu Set Mesin Jahit \\
\hline 9 & Anas Nur Cahyo & Alat Bengkel \\
\hline 10 & Denny Nur & Perit SVS Elektro \\
\hline 11 & Harjito & Ternak Kambing \\
\hline 12 & Sudaryanto & Ternak Ayam \\
\hline 13 & Aris & Modal Usaha Aquarium \\
\hline 14 & Yulianto & Modal Usaha Aquarium \\
\hline 15 & Dwi Yulianto & Peralatan Ternak Ayam \\
\hline 16 & Supriyanto & Peralatan Bengkel \\
\hline 17 & Riswanto & Modal Usaha Pecel Lele \\
\hline 18 & Eko Makalan & Modal Usaha Pecel Lele \\
\hline 19 & Sutrisno & Ternak Ikan Nila \\
\hline 20 & Yusnanto & Jual Kaos \\
\hline$S$ & ber Dokumen Rumah Singsh Diponegoro Yogyakta Tahun & \\
\hline
\end{tabular}

Sumber : Dokumen Rumah Singgah Diponegoro Yogyakarta Tahun 2007

h. Pembinaan Keagamaan

Pembinaan Keagamaan di sini dimaksudkan untuk pembinaan yang berkaitan dengan penangulangan kenakalan remaja, eksploitasi seks, kekerasan dan penyimpangan sosial yang sering terjadi dilakukan di jalanan. Rumah Singgah Diponegoro dalam melakukan pembinaan anak jalanan melalui pendekatan keagamaan dilakukan dengan kegiatan-kegiatan pemberian materi pembinaan mental agama Islam yang diberikan oleh pengurus dari Rumah Singgah Diponegoro Yogyakarta.

Pemberian materi mental spiritual keagamaan memberi dampak positif kepada anak-anak jalanan yang ada di Rumah Singgah Diponegoro, ini dapat dilihat pada saat peneliti melakukan observasi di Rumah Singgah Diponegoro. Karena sewaktu peneliti mengunjungi Rumah Singgah Diponegoro yang pertama kali mendapat perlakuan yang sangat sopan dan ramah dari anak jalanan yang tinggal di Rumah Singgah tersebut. Hal ini sangat jauh berbeda dengan angapan kebanyakan orang tentang karakter anak jalanan yang liar dan tidak memiliki aturan atau tata krama, ternyata anak jalanan setelah mendapat binaan dan penanganan yang serius dari Rumah Singgah dapat merubah karakter mereka 
menjadi anak yang memiliki sopan santun terhadap setiap orang dan tamu yang datang berkunjung ke Rumah Singgah Diponegoro.

\section{Program Lanjutan Pasca Rumah Singgah}

a. Kawasan Antara

Kawasan antara adalah lokasi atau laboratorium kerja bagi anakanak Pasca Rumah Singgah. Setelah mengikuti pendampingan tahap awal di Rumah Singgah, maka untuk selanjutnya mereka memasuki kawasan antara dengan tanah garapan seluas $4.500 \mathrm{~m} 2$, merupakan tanah pelunguh desa yang disewa oleh program ini sebagai laboratorium pasca Rumah Singgah. Kawasan anatara ini selain mengembangkan misi keilmuan juga memberi fasilitas program perikanan, pemancingan, peternakan dan usaha ekonomi produktif dengan melibatkan anak pasca Rumah Singgah.

Kawasan antara adalah kawasan semi kemasyarakatan dengan sistem dan manajemen yang dikelola oleh lembaga. Sehingga kawasan ini selain menyediakan sistem juga tersedia fasilitas lain, diantaranya kolam ikan dan usaha ekonomi produktif (siomay, bakso dan pecel lele). Ada dua hal penting yang dipersiapkan dalam kawasan ini, yaitu lokasi dan sistem. Lokasi Kawasan Antara tergolong strategis karena lingkungan yang hijau dan sangat berpotensi untuk diolah, dan sistem yang dibangun saat ini adalah membangun kawasan yang humanis, cinta lingkungan dan menumbuhkan minat dan bakat pada anak-anak melalui pemeliharaan potensi lingkungan.

b. Terminasi Pasca Kawasan Antara

Tahap terminasi ini yaitu tahap anak-anak yang sudah tidak mau ke jalanan. Sehingga pelayanan yang dilaksanakan juga sebagaimana mereka yang normatif pada umumnya. Mereka hidup sebagaimana kehidupan yang normal. Tahap terminasi adalah tahap akhir anak-anak atau keluarga yang telah melalui tahap Rumah Singgah dan Tahap Kawasan Antara. Pada tahap ini Rumah Singgah akan membantu anak jalanan untuk kembali kepada orang tuanya yang sudah lama ditinggalkan, untuk tahun 2007 tercatat sudah lima kali memulangkan anak jalanan kepada keluarganya, dari kelima anak tersebut adalah:

Tabel 5.

Reunifikasi anak dengan kelurga

\begin{tabular}{|l|l|l|}
\hline No & \multicolumn{1}{|c|}{ Nama } & \multicolumn{1}{c|}{ Alamat Asal } \\
\hline 1 & Fendy Friyanto & Temangung, Jawa Tengah \\
\hline 2 & Rustiyani & Tepus, Gunung Kidul \\
\hline 3 & Surtiningsih & Tepus, Gunung Kidul \\
\hline 4 & Yudi Satritono & Cempaka Putih, Jakarta \\
\hline 5 & Muhajir & Kebumen, Jateng \\
\hline
\end{tabular}

Sumber : Dokumen Rumah Singgah Diponegoro Yogyakarta Tahun 2007 
Dalam pengembalian anak jalanan dari pihak Rumah Singgah kepada orang tua merupakan kebangaan tersendiri bagi Rumah Singgah, karena mampu mengembalikan anak mereka setelah sekian lama berpisah dengan orang tuanya. Dari pihak keluarga mereka pun sangat berterima kasih kepada pihak Rumah Singgah.

\section{Kesulitan-kesulitan yang Dihadapi Rumah Singgah Diponegoro Yogyakarta dalam Upaya Pemberdayaan Anak Jalanan}

Banyak kesulitan dan hambatan yang dirasakan oleh Rumah Singgah Diponegoro Yogyakarta dalam upaya pemberdayaan anak jalanan, misalnya :

a. Kurang memiliki sumberdaya keuangan yang memadai untuk menjalankan program secara optimal

b. Kurang mendapat dukungan dari instansi terkait yang menangani masalah anak jalanan, sehingga dalam pelaksanaan program pemberdayaan anak jalanan kurang optimal.

c. Kurangnya sosialisasi keberadaan Rumah Singgah Diponegoro Yogyakarta dan pengenalan program pemberdayaan bagi anak jalanan , sehingga masih banyak anak jalanan yang tidak mengetahui keberadaan Rumah Singgah Diponegoro Yogyakarta. d. Adanya stigma buruk dari masyakat, sehingga Rumah singgah mengalami kesulitan untuk merujuk anak jalanan ke panti sosial atau orang tua asuh.

e. Banyak anak jalanan yang sudah mengikuti program pelatihan pemberdayaan yang turun ke jalanan lagi, karena tidak berani mempraktekan keahliannya di lapangan, hal ini disebakan oleh jiwa usaha yang masih rendah.

f. Kurangnya bantuan modal usaha untuk anak jalanan setelah mengikuti program pelatihan keterampilan, sehinggan anak jalanan mengalami ksesulitan untuk membuka awal usahanya sesuai dengan keahlian dan keterampilan yang pernah diperoleh di rumah singgah.

g. Jumlah pengurus dan pekerja sosial yang ada di Rumah Singgah terbatas sehingga dalam pembinaan anak jalanan tidak bisa optimal.

h. Angapan anak jalanan yang mengangap tidak penting mengikuti program pelatihan keterampilan, sehingga banyak anak jalanan yang lebih mementingkan mencari uang di jalanan dari pada ikut pelatihan ketrampilan di Rumah singgah.

\section{Potensi-potensi Rumah Singgah Dipoengoro Yogyakarta \\ Rumah Singgah Diponegoro dalam penyelengaraan kegiatan}


memilki Potensi dalam upaya pemberdayaan anak jalanan yaitu :

a. Memiliki struktur lembaga yang kuat

b. Memiliki basis anak-anak Jalanan sebagai sasaran program

c. Memiliki dukungan skill dan kemampuan pengelolaan pada setiap sisi pengelolaan, sehingga banyak programprogram dapat terlaksana dengan baik sesuai dengan harapan dan tujuan yang diharapkan. Hal ini disebabkan oleh Sumber Daya Manusia yang mendukung, karena penggurus dari Rumah Singgah Diponegoro adalah berpendidikan Sarjana. Sehingga setiap Program yang akan dilaksanakan selalu direncanakan dengan baik.

\section{Kesimpulan}

Dalam upaya pemberdayaan anak jalanan melalui Rumah Singgah Diponegoro Yogyakarta dilakukan melalui berbagai penyelenggaraan program pendidikan dan pelatihan keterampilan hidup sebagai berikut :

1. Penjangkauan dan identifikasi anak jalanan

2. Pemberian bantuan beasiswa

3. Pemberian bantuan makanan

4. Kesehatan

5. Pembinaan mental spiritual

6. Kursus keterampilan

Dari hasil penelitian anakanak jalanan pada umumnya berada pada usia sekolah, usia produktif yaitu antara usia 6-18 tahun, mereka mempunyai kesempatan yang sama seperti anak-anak yang lain, mereka adalah warga negara yang berhak mendapatkan pelayanan pendidikan, tetapi di sisi lain mereka tidak bisa meninggalkan kebiasaan mencari penghidupan di jalanan. Perlu disadari bahwa pelaksanaan program pelayanan sosial anak jalanan selama ini masih dirasa belum maksimal. Hal ini sebagai akibat dari fokus penanganannya lebih diutamakan pada sasaran program, kurang diimbangi dengan pendekatan kebutuhan yang diharapkan dari anak jalanan. Dalam hal ini diharapkan agar program penanganan anak jalanan lebih difokuskan pada kebutuhan personal anak. Pada akhirnya mampu memberikan jaminan bagi anak untuk berkembang secara normal.

\section{Daftar Pustaka}

Bagong Suyanto, PermasalahanPermasalahan Strategis dalam Program Pemberdayaan Ekonomi Kerakyatan. Surabaya: Airlangga University Press, 2002.

BKSN. Anak Jalanan Di Indonesia: Permasalahan dan Penanganannya. Jakarta : BKSN, 2000.

BPS 1403.34, Yogyakarta Dalam Angka. BPS Propinsi Daerah Istimewa Yogyakarta, Yogyakarta, 2002.

Depsos. Intervensi Psikososial. Jakarta : Direktorat kesejahteraan Anak Keluarga dan Lanjut Usia, 2001.

Depsos. Pelayanan Sosial Anak, Jakarata: Direktorat Jendral Pelayanan dan Rehabilitasi Sosial, 2002 
| Pemberdayaan Anak Jalanan

Artikel Surat Kabar/ Internet

Surat Kabar Minguan Pagi. 1

Desember 2001.

Astutik, D. (2005). Pengembangan

Model Pembinaan Anak Jalanan Melalui
Rumah Singgah di Jawa Timur.

Tersedia pada

http://www.damandiri.or.id/detail. php?id=325. Diakses pada tanggal 3 Januari 2008 